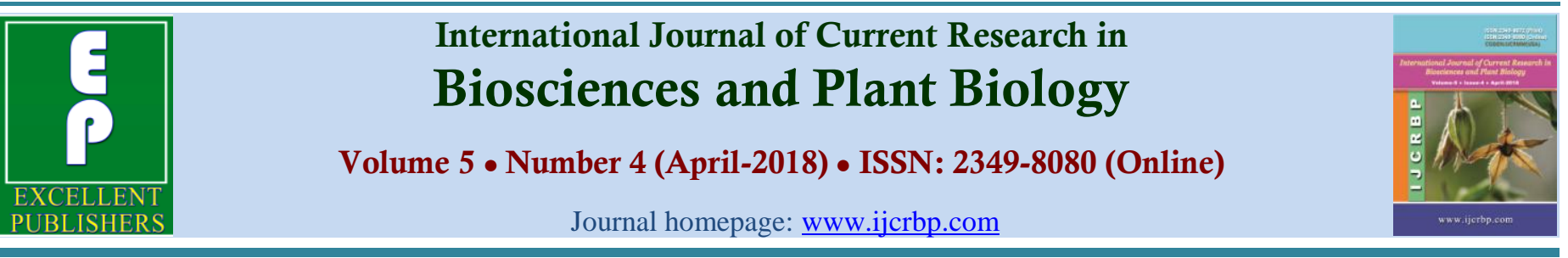

Original Research Article

doi: https://doi.org/10.20546/ijcrbp.2018.504.001

\title{
Epilithic Algae as a Biological Indicator in Sungai Suir Inside PT. Tidar Kerinci Agung Oil Palm Plantation
}

\section{Serly Marselina Arifin*, Jabang Nurdin and Chairul}

Biology Department, Faculty of Mathematics and Natural Sciences, Andalas University, Limau Manis-25163, Indonesia

*Corresponding author.

\section{Article Info \\ Date of Acceptance: \\ 22 March 2018 \\ Date of Publication: 06 April 2018}

\section{Keywords}

Biological indicator

Epilithic algae

Oil palm plantation

Sungai Suir

\begin{abstract}
A study about epilithic algae as biological indicator in the Sungai suir in the oil palm plantation area of PT. Tidar Kerinci Agung had conducted on April until August 2017. This research aims to know the composition of epilithic algae as biological indicator on the Sungai suir in oil palm plantation of PT. Tidar Kerinci Agung. This research is carried out by survey method and location of sampling determinates with purposive sampling. Determination of epilithic algae sampling station based on plantation activity of PT. Tidar Kerinci Agung. Sampling technique at each station using stratified random sampling. As a result, it has been found the epilithic algae of seven classes, Bacillariophyta, Chlorophyta, Cyanophyta, Dinophyta, Euglenophyta, Rhodophyta and Xanthopyta. The highest total epilithic algae density $\left(209.56 \mathrm{ind} / \mathrm{cm}^{2}\right)$ was found at station 3 and the lowest (101.38 ind $/ \mathrm{cm}^{2}$ ) was found at station 4 (downstream river). The dominant epilithic algae were Cymbella sp. 1, Gomphonema sp., Navicula lanceolata, Synedra sp. 1, Cylindrocapsa sp., Calothrix sp. and Lyngbya sp 2. Saphrobic coefficient was -1.88 until -0.28 .The result also showed that Sungai Suir was indicated pollution from moderately polluted tohigh level polluted. The nitrate concentrations ranged from 1.31 to $1.5 \mathrm{mg} / \mathrm{L}$, phosphate ranged from 4.33 to $4.66 \mathrm{mg} / \mathrm{L}$ and ammonia ranged from non-detectable to $0.49 \mathrm{mg} / \mathrm{L}$.
\end{abstract}

\section{Introduction}

Water ecosystem on land was generally divided into 2 groups, lentic water and lotic water. Lentic water also known as slow moving water had example like lake. Lotic water also known as fastmoving water had example like river or canal (Barus, 2004). A river has several roles in hydrological cycle, as water reservoir from catchment area, moving materials within water to short-flat area (Goldman and Horne, 1983). River as an ecosystem constructed with biotic and abiotic components. Each components was affected each other and created a flowing enery and materials that can support ecosystem stability (Suwondo et al., 2004). 
Epilithic Algae were micro-algae that attached on rocks inside the moving river (Dodds, 2002). All lives in the water, directly or indirectly, depend on the result of photosynthesis of algae and plant water. Both of them can change inorganic compounds into organic materials with the help from sunlight. This event only happened on plant that contained chlorophyll, one of them is algae. This organism hold important role as a primary producer beside water plants and another plants (Markland, 1987).

Sungai Suir is one of the rivers present inside PT. Tidar Kerinci Agung oil palm plantation. The edging of river has a variety of plantation from flat until non-flat. Some of those have wall of rocks, and make water flowing like a waterfall. The surrounding area of the river was dominated with secondary forest. Sungai Suir flow through inside the oil palm plantation of PT. Tidar Kerinci Agung (TKA) and meet with Sungai Jujuhan outside of this area.

The research had ever been conducted inside oil palm plantation was Olaleye (2005), Water quality and plankton as an effect of oil palm waste at Ondo, Nigeria. Besides that, the research about epilithic algae as a biological indicator has beenconducted by Purba (2015) in Sungai batang ombilin. Today, this research aims to study the composition of species of epilithic algae as biological indicator in Sungai Suir inside PT. Tidar Kerinci Agung oil palm plantation.

\section{Materials and Methods}

This study was conducted using survey methods and to determinate location of sampling using purposive sampling based on the activity of PT. Tidar Kerinci Agung plantation. It was determine to collect sample with four stations. The sample collection of epilithic algae used quadrant methods with measurement $20 \times 20 \mathrm{~cm}$. There were three repetitions inside each station.

Sampling algae used by brushing rocks that found inside the quadrant. Then, those rocks was brushed using soft brusher and then flush it with water inside the container.

Henceforth, the water after flushing those rocks was filtered using plankton net. Next, the water sample was moved in into sampling bottle and added $4 \%$ of formalin as a preservation. Sample was identified using books of identification namely Prescott (1979), Yamaji (1980), Biggs and Kilroy (1994), Cox (1996), Wehr and Sheath (2003), Vuuren et al. (2006), Taylor et al. (2007) and, Bellinger and Sigee (2010). Data analyses were done as per the details given below:

Epilithic Algae Density:

Where,

$$
\mathrm{K}=\frac{\mathrm{a} \times \mathrm{c}}{\mathrm{L}}
$$

$\mathrm{a}=$ Average totals of individuals of one species.

$\mathrm{c}=$ Volume of sample concentration

$\mathrm{L}=$ Wide $\left(\mathrm{cm}^{2}\right)$

$\mathrm{K}=$ Density $\left(\mathrm{Ind} / \mathrm{cm}^{2}\right)$

Relative Density:

$$
\mathrm{K}=\frac{\text { Density of one species }}{\text { Totals of density of all species }}
$$

Determination of water quality based on coefficient of Saprobe (Koesoebiono, 1987).

$$
X=\frac{C+3 D-B-3 A}{A+B+C+D}
$$

Where,

$X=$ coefficient of Saprobe ( -3 means around 3),

$\mathrm{A}=$ Group of organism Cyanophyta,

$\mathrm{B}=$ Group of organism Euglenophyta,

$\mathrm{C}=$ Group of organism Chlorophyta,

$\mathrm{D}=$ Group of organism Chrysophyta

The connection between coefficients of Saprobe (X) with level of damaging polluted water in Table 1. 
Table 1. The connection between coefficients of Saprobe (X) with level of damaging polluted water (Koesoebiono, 1987).

\begin{tabular}{|c|c|c|c|}
\hline Polluter & Pollution level & Phase saprobes & Coefficients of Saprobe \\
\hline \multirow{8}{*}{ Orhanic } & \multirow{4}{*}{ Very heavy } & Polisaprobik & $(-3)-(-2)$ \\
\hline & & Poli / $\alpha$-mesosaprobik & $(-2)-(-1.5)$ \\
\hline & & Polisaprobik & $(-3)-(-2)$ \\
\hline & & Poli / $\alpha$-mesosaprobik & $(-2)-(-1.5)$ \\
\hline & \multirow{4}{*}{ Quite heavy } & $\alpha-$ meso/ polisaprobik & $(-1.5)-(-1)$ \\
\hline & & $\alpha-$ mesosaprobik & $(-1.0)-(0.5)$ \\
\hline & & $\alpha-$ meso/ polisaprobik & $(-1.5)-(-1)$ \\
\hline & & $\alpha-$ mesosaprobik & $(-1.0)-(0.5)$ \\
\hline \multirow{7}{*}{ Organic and inorganic } & \multirow{4}{*}{ Middle } & $\alpha / \beta$-mesosaprobik & $(-0.5)-(0)$ \\
\hline & & $\beta / \alpha$-mesosaprobik & $(0)-(0.5)$ \\
\hline & & $\alpha / \beta$-mesosaprobik & $(-0.5)-(0)$ \\
\hline & & $\beta / \alpha$-mesosaprobik & $(0)-(0.5)$ \\
\hline & \multirow{4}{*}{ Light } & $\beta$-mesosaprobik & $(0.5)-(1.0)$ \\
\hline & & $\beta$-meso/oligosaprobik & $(1.0)-(1.5)$ \\
\hline & & $\beta$-mesosaprobik & $(0.5)-(1.0)$ \\
\hline \multirow{5}{*}{ Organic and inorganic } & & $\beta$-meso/oligosaprobik & $(1.0)-(1.5)$ \\
\hline & \multirow{4}{*}{ Very light } & Oligo/ $\beta$-mesosaprobik & $(1.5)-(2)$ \\
\hline & & Oligosaprobik & $(2.0)-(3.0)$ \\
\hline & & Oligo/ $\beta$-mesosaprobik & $(1.5)-(2)$ \\
\hline & & Oligosaprobik & $(2.0)-(3.0)$ \\
\hline
\end{tabular}

\section{Results and discussion}

Epilithic algae that found in Sungai Suir around oil palm plantation of PT. Tidar Krinci Agung belonged to seven class, Bacillariophyta, Chlorophyta, Cyanophyta, Dinophyta, Euglenophyta, Rhodophyta, and Xanthophyta (Table 2).

Total average density of epilithic algae on each stations was range between 101.38 - 209.56 $\mathrm{ind} / \mathrm{cm}^{2}$. The highest density found on station 3 , $209.56 \mathrm{ind} / \mathrm{cm}^{2}$, and the lowest is station 4 with $101.38 \mathrm{ind} / \mathrm{cm}^{2}$. The high density of station 3 was affected by location of this station near oil palm plantation and had many small rivers that coming from oil palm manufacturer. So many materials were dumped into the river and they change the condition of the river. On the other hand, condition of low density of total average epilithic algae at station 4 (downstream river) was affected by the topography of station 4 that was more flat than others were. This will affect the current to be slowly and the availability of epilithic algae decreased. According to Bergey (2008), substrate condition can change the speed, and different size of rocks can affect different density of epilithic algae. Many insect larvae that was grazer of algae, present on flat-surface rocks.

On the three taxa, there were found seven species that had relative density more than $>5 \%$, Cymbella sp. 1, Gomphonema sp., Navicula lanceolata, Synedra sp. 1 from Bacillariophyta. Cylindrocapsa sp. from Chlorophyta. Calothrix sp. and Lyngbya sp. 2 from Cyanophyta (Table 3), (Fig. 1). Jorgensen et al. (2005) stated that the value of relative density more than $5 \%$ is the dominant taxa.

The dominant species of can be effected by their numbers on the river. According to Welch and Jacoby (2005), epilithic algae community in the river was generally dominated by Diatoms, for instance, Navicula, Gomphonema, Diatoma, Cymbella, Cocconeis and Synedra. 
Table 2. Periphyton density $\left(\mathrm{ind} / \mathrm{cm}^{2}\right.$ ) on each taxa in Sungai suir inside the PT. Tidar Kerinci Agung oil palm plantation.

\begin{tabular}{lllll}
\hline \multirow{2}{*}{ Taxa } & \multicolumn{4}{l}{ Observation stations } \\
\cline { 2 - 5 } & $\mathbf{1}$ & $\mathbf{2}$ & $\mathbf{3}$ & $\mathbf{4}$ \\
\hline Bacillariophyta & 136.88 & 52.5 & 41 & 38.25 \\
Chlorophyta & 4.69 & 117.94 & 28.88 & 6.38 \\
Cyanophyta & 13.50 & 10.31 & 138.56 & 51.94 \\
Dinophyta & 1.13 & 0.33 & 0.56 & 0.50 \\
Euglenophyta & - & 0.67 & 0.38 & 4.31 \\
Rhodophyta & - & 2.67 & - & - \\
Xanthopyta & - & 0.17 & 0.19 & - \\
Total density & 156.19 & 184.58 & 209.56 & 101.38 \\
\hline
\end{tabular}

Noted: (-): nothing

Table 3. Relative density of epilithic algae (>5\%) on each taxa in Sungai Suir inside PT. Tidar Kerinci Agung oil palm plantation.

\begin{tabular}{|c|c|c|c|c|}
\hline \multirow{2}{*}{ Taxa } & \multicolumn{4}{|c|}{ Observation stations } \\
\hline & 1 & 2 & 3 & 4 \\
\hline \multicolumn{5}{|l|}{ A. Bacillariophyta } \\
\hline Cymbella sp. 1 & - & - & - & 5.91 \\
\hline Gomphonema sp. & - & 5.07 & - & - \\
\hline Navicula lanceolata & 62.06 & 10.44 & - & 10.72 \\
\hline Synedra sp. 1 & - & - & - & 6.28 \\
\hline \multicolumn{5}{|l|}{ B. Chlorophyta } \\
\hline Cylindrocapsa sp. & - & 60.39 & 11.18 & - \\
\hline \multicolumn{5}{|l|}{ C. Cyanophyta } \\
\hline Calothrix sp. & - & - & 63.67 & 14.79 \\
\hline Lyngbya sp. 2 & - & - & - & 35.12 \\
\hline
\end{tabular}

Species of Navicula lanceolata was dominant at each station except station three. The dominance of Navicula lanceolata at each station can be caused by its many numbers in the freshwater environment and its ability to move without flagella, but using mucilage which it is a liquid presented on its surface body. The presence of Navicula lanceolata was widely spread on variety aquatic condition (Bellinger and Sigee, 2010).

Gomphonema sp. was dominant only at station 3 because it usually found attached on substrate by using its root. In general, it can live on difference aquatic condition.

Valuing of water quality based on coefficient of saprobes $(\mathrm{X})$

Saprobes system has role to know dominant organism and its numbers in term of deciding level of pollution. The value of saprobes coefficient in this study was ranged from -1.88 until -0.28 (Table 4). Based on the correlation between saprobes coefficient and aquatic polluted levels by Dresscher and van der Mark (Ravera, 1979), Sungai Suir was get into medium polluted level with phase $\alpha / \beta$ mesosaprobik on station 2 and 4. Station 1 was belonging to hardly polluted level with phase $\alpha-$ mesosaprobik, and station 3 belongs into heavily polluted level with phase Poli / $\alpha$-mesosaprobik.

Vegetation of oil palm plantation that dominates station 3 caused no protection of soil particle then it went directly get in to the water column. Station 3 was located on Sungai Suir that flowing through plantation areal around $\pm 7.9 \mathrm{~km}$ from station 2 . These are effects of plantation activity for instance fertilizer and pesticide, and accumulate activity of plantation with $16.6 \mathrm{~km}$ long from station 1 and 3 . The nitrate concentrations in the study sites ranged 
from 1.31 to $1.5 \mathrm{mg} / \mathrm{L}$ while the levels of phosphate ranged from 4.33 to $4.66 \mathrm{mg} / \mathrm{L}$ and ammonia ranged from non-detectable to $0.49 \mathrm{mg} / \mathrm{L}$ (Table 5).
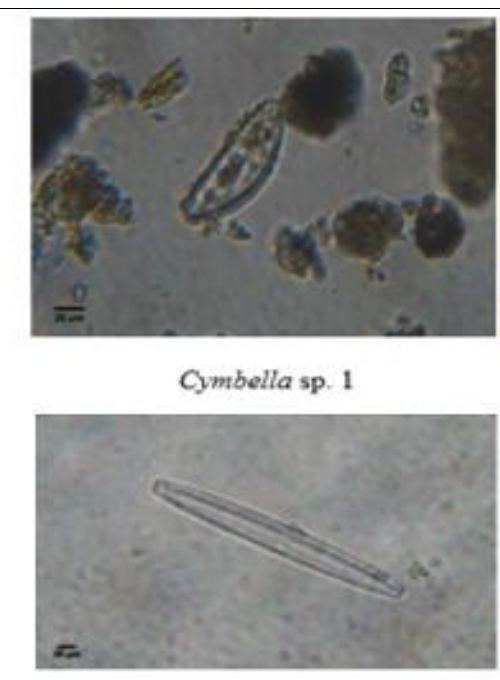

Synedra sp. 1

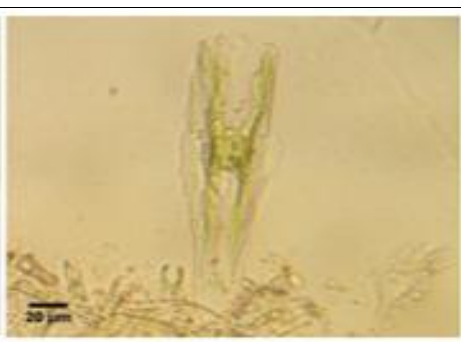

Ghomponema sp.

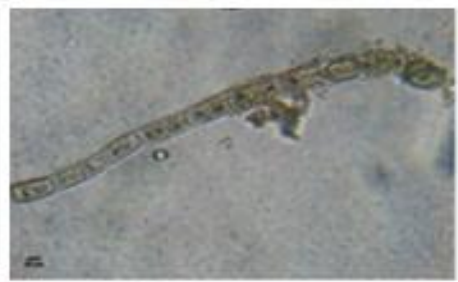

Clindrocapsa sp.

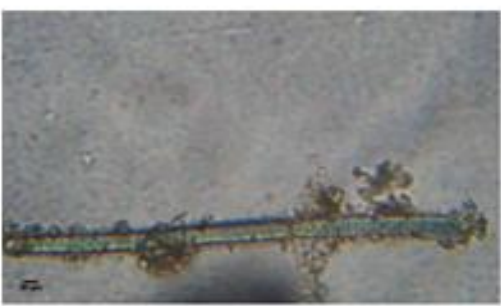

Lyngbya sp. 2

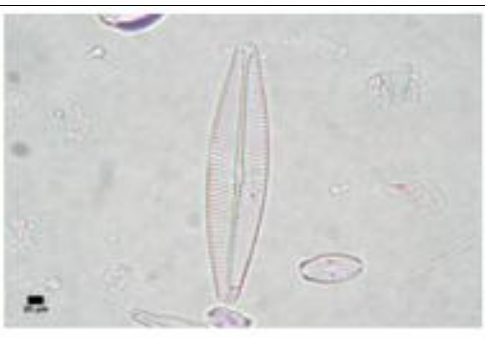

Navicula lanceolata

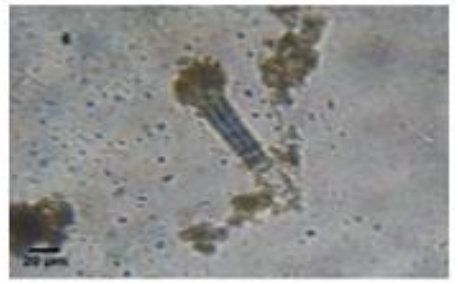

Calothrix sp.

Fig. 1: The dominant epilithic algae in Sungai Suir inside PT. Tidar Kerinci Agung oil palm plantation.

Table 4. Value of saprobes coefficient and its connection with pollution level on each taxa in Sungai Suir inside PT. Tidar Kerinci Agung oil palm plantation.

\begin{tabular}{|c|c|c|c|c|c|}
\hline \multirow{2}{*}{ Groups } & \multirow{2}{*}{ Taxa } & \multicolumn{4}{|c|}{ Observation stations } \\
\hline & & 1 & 2 & 3 & 4 \\
\hline $\bar{A}$ & Cyanophyta & 7 & 4 & 11 & 4 \\
\hline B & Euglenophyta & 0 & 1 & 1 & 1 \\
\hline $\mathrm{C}$ & Chlorophyta & 8 & 9 & 4 & 6 \\
\hline $\mathrm{D}$ & Chrysophyta & 0 & 0 & 0 & 0 \\
\hline Saprobes coefficient $(\mathrm{X})$ & & -0.86 & -0.28 & -1.88 & -0.54 \\
\hline Saprobes phase & & $\alpha$-mesosaprobik & $\begin{array}{l}\alpha / \beta- \\
\text { mesosaprobik }\end{array}$ & $\begin{array}{l}\text { Poli / } \alpha- \\
\text { mesosaprobik }\end{array}$ & $\begin{array}{l}\alpha / \beta- \\
\text { mesosaprobik }\end{array}$ \\
\hline Pollution level & & Quite heavy & Medium & Very heavy & Medium \\
\hline
\end{tabular}

Table 5. Chemical parameter of waters in Sungai Suir inside PT. Tidar Kerinci Agung oil palm plantation.

\begin{tabular}{lllll}
\hline \multirow{2}{*}{ Parameter } & Stasiun Pengamatan & & & \\
\cline { 2 - 5 } & $\mathbf{1}$ & $\mathbf{2}$ & $\mathbf{3}$ & $\mathbf{4}$ \\
\hline Nitrate $\mathrm{mg} / \mathrm{L}$ & 1.31 & 1.5 & 1.32 & 1.48 \\
Phosphate mg/L & 4.66 & 4.33 & 4.62 & 4.64 \\
Ammonia mg/L & Not oberved & 0.49 & 0.48 & 0.49 \\
\hline
\end{tabular}


With the high level of pollution at station 3 , it was caused by Calothrix sp. density is higher than others (Table 3). Besides that, station 3 was located inside of oil palm plantation and had many small rivers that flowing through oil palm manufacturer. This caused many materials from manufacturer get into the river and affected the river condition.

The highest nitrate concentration is at station 2, while the lowest is at station 1 , whereas the highest concentration of phosphate is at station 1 and lowest at station 2 . The ammonia concentration at stations 2, 3 and 4 is almost the same concentration but at station 1 ammonia is not detected. However, levels of nitrate, phosphate and ammonia in each station are not significantly different. Effendi (2003) said the main source of nitrate in the waters comes from agricultural areas and plantations that use fertilizers intensively.

Classification of water fertility can be seen based on nitrate level, ie oligotrophic waters when nitrate level between 0-1 mg / L, mesotrophic waters between 1-5 mg / L and eutrophic waters ranged between 5-50 mg / L (Wetzel, 1975). Based on the classification, the oil palm plantation of Tidar Kerinci Agung is classified as mesotrophic waters.

In low-water ammonia waters are found because ammonia is soluble in water and the transition form of ammonia is an ammonium ion. Ammonia is widely used in the production of urea and chemical industry. The free ammonia content that is not ionized in fresphwater is not more than $0.2 \mathrm{mg} / \mathrm{L}$.

High levels of ammonia can be an indication of the contamination of organic materials derived from domestic waste, industrial and agricultural fertilizer runoff. Ammonia in the palm oil plantation rivers PT Tidar kerinci Agung is in the dud into the water through soil erosion.

From all the results in this study, it can be concluded that total average density of epilithic algae at each stations around 101.38 - 209.56 $\mathrm{ind} / \mathrm{cm}^{2}$. The dominant species are Cymbella sp. 1, Gomphonema sp., Navicula lanceolata, Synedra sp.
1, Cylindrocapsa sp., Calothrix sp. and Lyngbya sp. 2. The value of Saprobes Coefficient in this study is -1.88 to -0.28 and get in into medium until very heavy pollution level.

The nitrate concentrations in the study sites ranged from 1.31 to $1.5 \mathrm{mg} / \mathrm{L}$ while the levels of phosphate ranged from 4.33 to $4.66 \mathrm{mg} / \mathrm{L}$ and ammonia ranged from non-detectable to $0.49 \mathrm{mg} / \mathrm{L}$.

\section{References}

Barus, T. A., 2001. Pengantar Limnologi Studi Tentang Ekosistem Sungai dan Danau. USU Press. Medan.

Bellinger, E.G., Sigee, D. C., 2010. Freshwater Algae: Identification and Use as Bioindicators. Wiley-Blackwell, UK.

Bergey, E.A., 2008. Does rock chemistry affect periphyton accrual in rivers. Hidrobiologia. 614(3), 141-150.

Dodds, W. K., 2002. Freshwater Ecology. Academic Press, USA.

Goldman, C. R., Horne, A.J., 1983. Limnology. McGraw Hill International Book Company, London.

Jorgensen, S. E., Costanza, R., Xu, F., 2005. Ecological Indicators for Assessment of Ecosystem Health. Taylor \& Francis Group, United States.

Koesoebiono, 1987. Metode dan Teknik Pengukuran Biologi Perairan. Kursus AMDAL Angkatan V. Bogor.

Markland, H. R., 1987. Decaying Lake: The Origin and Control of Culture Eutrophication. JohnWiley \& Sons Inc., New York.

Olaleye, V. H., 2005. Water and planktonic quality of a palm oil effluent impacted river in Onde State, Nigeria. Int. J. Zool. Res. 1(1), 15-20.

Purba, I.Y.S., Izmiarti, Solfiyeni, 2015. Epilithic algae community as biological indicator in Sungai Batang Ombilin, Sumatera Barat. J. Biol. Univ. Andalas. 4(2), 138-144 (In Indonesian).

Ravera, O., 1979. Biological Aspect of Freshwater Pollution. Pergamon Press, London. 
Suwondo, Febrita, E., Dessy, Alpusari, M., 2004. Biological quality of river water in Sungai Senapelan, Sago and Sail at Pekanbaru City based on the bio-indicator of plankton and benthos. J. Biogenesis. 1(1), 15-20. (In
Indonesian).

Welch, E. B., Jacoby, J. M., 2005. Pollutant Effects in Freshwater. Spon Press, New York.

Wetzel, B. E., 1975. Limnology $2^{\text {nd }}$ Edn. Saunders College Publishing, Oxford, Philadelphia.

\section{How to cite this article:}

Arifin, S. M., Nurdin, J., Chairul, 2018. Epilithic algae as a biological indicator in Sungai Suir inside Pt. Tidar Kerinci Agung oil palm plantation. Int. J. Curr. Res. Biosci. Plant Biol. 5(4), 1-7.

doi: https://doi.org/10.20546/ijcrbp.2018.504.001 